\title{
Exploratory Study on Infant Development under Institutional Sheltering in the North Region of Brazil
}

\author{
Janari da Silva Pedroso1,2, Greicyani Brarymi Dias', Celina Maria Colino Magahães, \\ Edson Júnior Silva da Cruz ${ }^{1}$ \\ ${ }^{1}$ Federal University of Pará-UFPA, Belém, Brazil \\ ${ }^{2}$ Catholic University of Brasília-UCB, Taguatinga, Brazil \\ Email: pedrosoufpa@gmail.com
}

Received 11 February 2015; accepted 28 February 2015; published 3 March 2015

Copyright (C) 2015 by authors and Scientific Research Publishing Inc.

This work is licensed under the Creative Commons Attribution International License (CC BY). http://creativecommons.org/licenses/by/4.0/

c) (i) Open Access

\begin{abstract}
This study analyzed the child development through mental, motor, and behavioral assessment of twenty babies with ages from 1 to 12 months, who were part of an institutional sheltering service in the North region of Brazil. The babies were conveniently selected; the criteria were the absence of neurological problems and to be housed in the institution for longer than one month. The instrument used was the Bayley Scale of Infant Development (BSID-II). The socio-demographic data of the sample indicated that babies were welcomed in the institution for either reasons, family abandonment or negligence, in addition, their stay in the shelter has already lasted from one to nine months, and $50 \%$ of them had drug-abusing mothers. The assessment of the scales indicated that $70 \%$ of babies, in average, had performances in the normal limits of development, and $30 \%$ of them presented problems. The results contribute to demonstrating the use of this assessment method such as supporting institutional measures in elaborating the individual assistance plan, along with other information as social, family, and medical history, aiming at offering quality assistance directed to the development of babies and children assisted by institutions.
\end{abstract}

\section{Keywords}

Babies, Bayley Scales, Child Development Assessment, Institutional Sheltering

\section{Introduction}

Several laws were elaborated in the last years with the aim to decrease the number of children that live in shelter

How to cite this paper: Pedroso, J. da S., Dias, G. B., Magahães, C. M. C., \& Cruz, E. J. S. da (2015). Exploratory Study on Infant Development under Institutional Sheltering in the North Region of Brazil. Psychology, 6, 305-313.

http://dx.doi.org/10.4236/psych.2015.64031 
institutions around the world. In Brazil, the amount of children and adolescents sheltered in institutions are close to 30 thousand, according to The National Council of Public Ministry (Conselho Nacional do Ministério Público -CNMP, 2013). In 2009, the Law 12.010 was created (Brasil, 2009), which lead to changes in sheltering and adoption, from which are stressed: the child won't stay in shelter for longer than two years, in addition, their legal condition must be re-assessed every six months; the family is the main return locus of the child; technicians are obliged to elaborate an individual assistance plan (IAP); the places previously called shelters are now named sheltering institutions. Upon the implementation of this law the matter of time spent by the children in this institution is a hard premise, still not followed by some services of institutional sheltering in Brazil (Oliveira \& Pereira, 2011; Corrêa \& Cavalcante, 2013).

Early age at entering the institution, period of sheltering, and types of care received are variables considered by many scholars as crucial elements for the incidence of delays in the development of babies in such places. However, it is discussed whether the changes in the psychomotor development are due to violence that took place before the sheltering, or on the contrary, are originated by prolonged sheltering, and whether these places would certainly remain as keepers of this delay (Van Ijzendoorn et al., 2011; Tizard \& Tizard, 1967; Tizard \& Joseph, 1970; Siqueira \& Dell’Aglio, 2006; Manso, Garcia-Baamonde, \& Alonso, 2011). Nonetheless, other studies state that without detection and intervention, when necessary, this scenery may lead to future problems in older ages, as the rising of other incapabilities, for example those presented at school related to difficulties in essential areas for learning (Schlesiger et al., 2011; Conti et al., 2012; Cardona, Manes, Escobar, López, \& Ibáñez, 2012).

Early identification of delay is not an easy task, the children that have difficulties in acquiring skills but can reach the normal development marks must be detached from those that truly suffer a deviation from the standard pattern for a given age. Therefore, the early recognition of developmental delay requires a deep knowledge of the skills predecessors. When combined early detection of delay and interventions are performed, the loss of important psychomotor development marks may be avoided (Soysal et al., 2014).

For an early identification of problems linked to the development of babies some assessments may be used through the psychosocial history, reports of the responsible people, information related to health, in addition to tests and scales. In Brazil the Bayley Scale of Infant Development (BSID-II) is continuously used in researches through translations, though without standardization for this population. That happens due to the lack of national tools or neurological tests adapted to the country's reality. The use of this instrument, according to the norms and care in translation are important for guiding the process of child assessment, especially in countries where the standardization of tests and tools are poor, chiefly concerning children in social vulnerability (Reis, Mello, Morsch, Meio, \& Silva, 2012; Cruz, Dias, \& Pedroso, 2014).

For Bayley (1993), BSID II is characterized as theoretically eclectic, its content is derived from several other development scales and a broad set of researches with babies and children. Its methodology enabled the understanding of several viewpoints represented in scales, without a specific theory that drives the content. It reaches samples of several emerging skills and lists the fixation of development marks. The scale results can be used for the identification of areas with relative deficiency or delay, thus develop intervention programs, besides evaluating the feedback of such interventions, when necessary. Nonetheless, for a more precise diagnose, which is presupposed by this scale, information of multiple sources must be gathered from medical and psychosocial files of the children.

The current research recognizes the importance of augmenting the knowledge on child development for it is necessary to investigate other determinants that may be involved in the variation of the development of babies under the care of sheltering institutions, such as: physical abuse, negligence, and abandonment. From this perspective, it is known that biological problems may be modified by environmental factors and is determined by vulnerability situations of varied etiology. Therefore, this study aimed at assessing babies in sheltering situations, using Bayley II scale, for the comprehension of a psychomotor development profile, giving emphasis to aspects related to the comprehension of cognitive, motor, language, and behavioral development level, besides the qualitative aspects of behavior.

\section{Method}

\subsection{Participants}

20 babies who were sheltered in an institution who attended children from zero to six years old, both genders, in 
social vulnerability situation were separately assessed. The sample was intentional, non probabilistic, excluding babies with the diagnose of neurological changes and giving priority to those with higher probability of staying in the institution. The designed age range was from 1 to 12 months, due to the few studies performed with babies in this context, additionally it is contained in the age demands established by the Bayley II scale. The application period with each baby was 30 minutes, in average.

\subsection{Environment}

The institution is set in the North region of Brazil, and may attend up to 50 children, though, frequently welcomes a larger number of children. The common area are two nursery rooms, five dormitories, two bathrooms, a room for stimulating the babies, a multimedia room for psycho-pedagogical and artistic-cultural activities, a toy library, a cafeteria, backyard with trees, and at the back a brick house, and a sheltered area for recreation (the shed).

\subsection{Instruments}

\subsubsection{Bayley Scales of Infant Development-BSID-II}

Bayley II is composed of three complementary sub-scales that aim at identifying the psychomotor development index, and detect delays in the development of children aging from 1 to 42 months. The main assessed aspects by each sub-scales are: 1) mental scale (the functioning of sensory and perceptive capabilities), it includes items that evaluate: memory, adaptation, problem-solving skills, primary concepts of numbers, classification, generalization, vocalization, language, and social skills; 2) motor scale (fine and gross motricity), evaluates the control of general and specific muscles groups, which includes movements associated to rolling, crouching, crawling, sitting, standing, walking, running, and jumping. This scale also tests little motor manipulations that gathers apprehension, the adapted use of writing tools, and imitation of hand movements.

The third behavioral scale-Behavior Rating Scales-BRS (qualitative evaluation of the interaction of children with objects and people) evaluates qualitative aspects of the child's behavior during a test considering the time for habituation with the babies. This scale enables the evaluator to assess aspects related to the emotional regulation, the child's attention/arousal, orientation/engagement, and the quality of motor movements. Emotional regulation contains items related to the adaptability, cooperation, persistence, frustration, and tolerance. It is also associated to the temper and quality of humor of the child. The factor attention/arousal has items associated to situations of alertness and attention of the babies up to 5 months old, hence, how it may respond to environment stimulus. The factor orientation/engagement deals with the behavioral tendency of a child to approach or move away from tasks related to environmental and social interactions. On the other hand, the motor quality evaluates a variety of neuromotor functions that may be observed in childhood. Among them are the muscular tonus, gross and fine motor control, bradykinesia (slow movements) and quality of movements. The information of the behavioral scale must be used as complementary to the ones obtained by the Mental and Motor Scales.

\subsubsection{Information from the Children's Chats}

The information regarding gender, age, health condition, reason of sheltering, time in the institution, and socio and legal situations were obtained from individual files of each baby.

\subsection{Procedure}

For the research to be developed according to ethical parameters, at first the legal authorization was sought on account that the babies that participated were under the State guard, represented by court authority. On the continuance, the research was subjected and received approval from the research ethics committee with human beings. The data collection took place between the months of January and July, 2012.

The babies were selected according to the criteria already mentioned, the sessions for applying the scale were performed by the researchers, in a room provided by the institution in periods and time that the children would be in an alert state. The evaluation was individual and took place only once and in the presence of the baby's educator. Before applying the scale the evaluator would interact with the child in order to decrease the unfamiliarity and situational anxiety. During the application it was followed the norms of the manuals and forms to register the performance of children in each item, and the standard abbreviations of the Bayley scale were used, in 
which are contained: C (Credit), the child replied or performed as expected and scored a point for the item; NC (No credit), the child replied or performed incorrectly and didn't score a point for the item; and RF (Refused) in which the child refused to perform the task and didn't receive credit for the item. The points were then added up and verified the raw scores and development indexes. This is a quantitative study with the use of descriptive statistical analysis by calculating frequency and percentage of the data collected from the charts and indicators obtained from the Bayley scale of child development.

\section{Results and Discussion}

The psychosocial characterization of babies was accomplished through the individual charts analysis. Generally, the determinant reasons for sheltering were abandonment and family negligence. This indicates that in $85 \%$ of the cases they were found unattended, or accompanied by young siblings, or left with unacquainted people.

Health negligence with these children, upon arriving the institution, was also another important factor, fourteen children (70\%) had some kind of disease as: viruses, skin rashes, or congenital diseases as syphilis and HIV. Therefore, the basic necessities for survival of the babies were not being attended. Such indexes corroborate Müller's study (2014) on the reasons for sheltering in Brazil, in which it was found that family negligence is a cause, but also a consequence of the social vulnerability this population is inserted due to the lack of implementation of public policies.

Another factor analyzed in the information from the charts and demonstrated by Table 1 is the use of psychoactive substances identified in 50\% of the children's mothers evaluated in the study. This data along with negligence and abandonment are in agreement with the last indexes released by CNMP (2013) that state the drug use of parents from institutionalized children appear as the main reason for sheltering in Brazil. Several of these factors related to physical assaults carried out by the ones responsible for these children, previous to sheltering, are capable of causing impairments to the child development, therefore, upon detection they must be fixed the best way possible (Golin \& Benetti, 2013).

In the present study it was noted by the sociodemographic data that half of the babies had drug abuser mothers, which could indicate a compromised performance of the babies in the scales. Such evidence is confirmed by Bayley (1993) in studies with children exposed to drugs in the pre-natal period, the results from Bayley II Scale indicated that the babies had performances below average in the mental scale, when compared to other babies with the same age. Nelson, Bos, Gunnar, \& Sonuga-Barke (2011) and Pajulo et al. (2012), also stressed in their studies that the use of drugs by mothers may affect negatively the development of the children's brain.

The mental development index assessments presented in Table 2 demonstrate that from the twenty children assessed $70 \%$ in average had results in the normal range for their age, while $30 \%$ are underdeveloped for their age, demonstrating profiles slightly or severely delayed. Nonetheless, as signed by the scale, they didn't score in essential aspects, such as those that relate to the personal-social development, attention, language, and recognition memory, in other words, aspects mainly related to cognition. Similar results were reported by Desmarais, Roeber, Smith and Pollak (2012) in their research on the memory of adopted babies. The authors emphasize that damages acquired early by babies, in areas as memory and language, may have influence on difficulties in learning during school phase.

Regarding the personal-social area for analyzing if the behavior is socially directed to the environment since they are two months old, it was verified in this study that some personal-socio behavior skills identified in mental and behavioral scales showed development indexes between the normal range, as: smile to the examiner, looks at people, is responsive to vocalization, and stare at the examiner.

The results obtained from the analysis of the babies' behavior scale are described in Table 3. It is observed that babies C4, C5, and C17 have non optimal profiles for the orientation/engagement factor and emotional regulation. Behavior changes are found in several studies with institutionalized children, either in literature classics or in more recent studies (Spitz, 2004; Tizard \& Rees, 1974; Smyke et al., 2012; Barcons et al., 2012; McLaughlin, Fox, Zeanah, \& Nelson, 2011). Muhamedrahimov et al. (2014) agree that behavioral changes along the development are recurrent when children in sheltering institutions are assessed and followed, and one of the possible ways to intervene in those cases is the socio-emotional support of the caretaker. Therefore, the institution must favor a sensitive and consistent care, motivating interactions between the babies and peers, and reference people for establishing attachment relationship, in addition to an environment rich in pleasant stimuli and diverse and age appropriate objects. Thus, it is necessary to invest in technical training of caretakers, as well as offering support to caretakers/educators which take care of the babies and children (Corrêa \& Cavalcante, 2013). 
Table 1. Psychosocial characterization of the babies.

\begin{tabular}{|c|c|c|c|c|c|}
\hline Child's name & Age & Entrance age & Entrance reason & Drug abuser parents & Presence of disease \\
\hline $\mathrm{C} 1$ & $2 \mathrm{~m} 19 \mathrm{~d}$ & $5 \mathrm{~d}$ & FN & NI & $\mathrm{N}$ \\
\hline $\mathrm{C} 2$ & $2 \mathrm{~m} 19 \mathrm{~d}$ & $13 \mathrm{~d}$ & A & NI & $\mathrm{Y}$ \\
\hline $\mathrm{C} 3$ & $1 \mathrm{~m} 1 \mathrm{~d}$ & $8 \mathrm{~d}$ & FN & $\mathrm{Y}$ & $\mathrm{N}$ \\
\hline $\mathrm{C} 4$ & $11 \mathrm{~m}$ & $8 \mathrm{~m} 20 \mathrm{~d}$ & A & NI & $\mathrm{Y}$ \\
\hline C5 & $3 \mathrm{~m} 17 \mathrm{~d}$ & $4 \mathrm{~d}$ & SV & NI & $\mathrm{Y}$ \\
\hline C6 & $2 \mathrm{~m} 25 \mathrm{~d}$ & $5 \mathrm{~d}$ & SS & NI & NI \\
\hline $\mathrm{C} 7$ & $12 \mathrm{~m}$ & $8 \mathrm{~m} 10 \mathrm{~d}$ & A & $\mathrm{Y}$ & $\mathrm{Y}$ \\
\hline $\mathrm{C} 8$ & $5 \mathrm{~m} 23 \mathrm{~d}$ & $5 \mathrm{~m}$ & FN & $\mathrm{Y}$ & $\mathrm{N}$ \\
\hline C9 & $7 \mathrm{~m}$ & $6 \mathrm{~m} 20 \mathrm{~d}$ & A & $\mathrm{Y}$ & $\mathrm{N}$ \\
\hline C10 & $4 \mathrm{~m} 28 \mathrm{~d}$ & $23 \mathrm{~d}$ & SV & NI & $\mathrm{Y}$ \\
\hline C11 & $5 \mathrm{~m} 2 \mathrm{~d}$ & $14 \mathrm{~d}$ & A & NI & $\mathrm{Y}$ \\
\hline C12 & $1 \mathrm{~m} 15 \mathrm{~d}$ & $13 \mathrm{~d}$ & A & NI & $\mathrm{Y}$ \\
\hline $\mathrm{C} 13$ & $2 \mathrm{~m} 4 \mathrm{~d}$ & $14 \mathrm{~d}$ & A & $\mathrm{Y}$ & $\mathrm{Y}$ \\
\hline C14 & $1 \mathrm{~m}$ & $7 \mathrm{~d}$ & A & $\mathrm{Y}$ & $\mathrm{Y}$ \\
\hline C15 & $5 \mathrm{~m} 20 \mathrm{~d}$ & $23 \mathrm{~d}$ & A & $\mathrm{Y}$ & $\mathrm{Y}$ \\
\hline C16 & $2 \mathrm{~m} 13 \mathrm{~d}$ & $2 \mathrm{~m} 1 \mathrm{~d}$ & A & $\mathrm{Y}$ & NI \\
\hline C17 & $8 \mathrm{~m} 8 \mathrm{~d}$ & $4 \mathrm{~m} 5 \mathrm{~d}$ & A & NI & $\mathrm{Y}$ \\
\hline C18 & $9 \mathrm{~m} 21 \mathrm{~d}$ & $1 \mathrm{~d}$ & FN & $\mathrm{Y}$ & S \\
\hline C19 & $9 \mathrm{~m} 25 \mathrm{~d}$ & $5 \mathrm{~m} 9 \mathrm{~d}$ & A & $\mathrm{Y}$ & S \\
\hline $\mathrm{C} 20$ & $11 \mathrm{~m} 7 \mathrm{~d}$ & $8 \mathrm{~m} 8 \mathrm{~d}$ & A & NI & $\mathrm{Y}$ \\
\hline
\end{tabular}

Note: m—Months; d—Days; A—Abandonment; FN—Family negligence; SV—Social vulnerability; NI—Not informed; N—No; Y—Yes.

Table 2. Characterization and indexes of mental development of babies.

\begin{tabular}{|c|c|c|c|}
\hline Name & Age & Period of institutional sheltering & IDM \\
\hline $\mathrm{C} 1$ & $2 \mathrm{~m} 19 \mathrm{~d}$ & $2 \mathrm{~m} 14 \mathrm{~d}$ & BNR \\
\hline $\mathrm{C} 2$ & $1 \mathrm{~m} 3 \mathrm{~d}$ & $21 \mathrm{~d}$ & BNR \\
\hline C3 & $1 \mathrm{~m} 1 \mathrm{~d}$ & $24 \mathrm{~d}$ & BNR \\
\hline $\mathrm{C} 4$ & $11 \mathrm{~m}$ & $2 \mathrm{~m}$ & SDP1 \\
\hline C5 & $3 \mathrm{~m} 17 \mathrm{~d}$ & $3 \mathrm{~m} 13 \mathrm{~d}$ & SDP1 \\
\hline C6 & $2 \mathrm{~m} 25 \mathrm{~d}$ & $2 \mathrm{~m} 20 \mathrm{~d}$ & BNR \\
\hline $\mathrm{C} 7$ & $12 \mathrm{~m}$ & $3 \mathrm{~m} 12 \mathrm{~d}$ & BNR \\
\hline C8 & $5 \mathrm{~m} 23 \mathrm{~d}$ & $24 \mathrm{~d}$ & BNR \\
\hline C9 & $7 \mathrm{~m}$ & $3 \mathrm{~d}$ & BNR \\
\hline C10 & $4 \mathrm{~m} 28 \mathrm{~d}$ & $4 \mathrm{~m} 5 \mathrm{~d}$ & BNR \\
\hline C11 & $5 \mathrm{~m} 2 \mathrm{~d}$ & $4 \mathrm{~m} 21 \mathrm{~d}$ & BNR \\
\hline C12 & $1 \mathrm{~m} 15 \mathrm{~d}$ & $1 \mathrm{~m} 2 \mathrm{~d}$ & BNR \\
\hline C13 & $2 \mathrm{~m} 4 \mathrm{~d}$ & $1 \mathrm{~m} 20 \mathrm{~d}$ & BNR \\
\hline C14 & $1 \mathrm{~m}$ & $23 \mathrm{~d}$ & BNR \\
\hline C15 & $5 \mathrm{~m} 20 \mathrm{~d}$ & $4 \mathrm{~m} 27 \mathrm{~d}$ & SDP2 \\
\hline C16 & $2 \mathrm{~m} 13 \mathrm{~d}$ & $13 \mathrm{~d}$ & BNR \\
\hline C17 & $8 \mathrm{~m} 8 \mathrm{~d}$ & $4 \mathrm{~m} 3 \mathrm{~d}$ & SDP2 \\
\hline C18 & $9 \mathrm{~m} 21 \mathrm{~d}$ & $9 \mathrm{~m} 20 \mathrm{~d}$ & BNR \\
\hline C19 & $9 \mathrm{~m} 25 \mathrm{~d}$ & $5 \mathrm{~m} 9 \mathrm{~d}$ & SDP1 \\
\hline C20 & $11 \mathrm{~m} 7 \mathrm{~d}$ & $2 \mathrm{~m} 30 \mathrm{~d}$ & SDP1 \\
\hline
\end{tabular}

Note: $\mathrm{m} —$ Months; d—Days; IMD—Index of mental development; BNR—Between normal range; AP—Accelerated profile; SDP1—Slightly delayed profile; SDP2—Severely delayed profile. 
Table 3. Characterization of the babies behavioral performance.

\begin{tabular}{|c|c|c|c|c|c|c|}
\hline Name & Age & $\begin{array}{l}\text { Attention/ } \\
\text { arousal factor }\end{array}$ & $\begin{array}{l}\text { Orientation/ } \\
\text { engagement factor }\end{array}$ & $\begin{array}{l}\text { Emotional regulation } \\
\text { factor }\end{array}$ & $\begin{array}{l}\text { Quality of } \\
\text { movement factor }\end{array}$ & $\begin{array}{l}\text { Total } \\
\text { rank }\end{array}$ \\
\hline C1 & $2 \mathrm{~m} 19 \mathrm{~d}$ & BNR & NA & NA & BNR & BNR \\
\hline C2 & $2 \mathrm{~m} 19 \mathrm{~d}$ & BNR & NA & NA & BNR & BNR \\
\hline C3 & $1 \mathrm{~m} 1 \mathrm{~d}$ & BNR & NA & NA & BNR & BNR \\
\hline C4 & $11 \mathrm{~m}$ & NA & NO & NO & $\mathrm{Q}$ & NO \\
\hline C5 & $3 \mathrm{~m} 17 \mathrm{~d}$ & BNR & NA & NA & BNR & BNR \\
\hline C6 & $2 \mathrm{~m} 25 \mathrm{~d}$ & BNR & NA & NA & BNR & BNR \\
\hline C7 & $12 \mathrm{~m}$ & NA & BNR & BNR & BNR & BNR \\
\hline $\mathrm{C} 8$ & $5 \mathrm{~m} 23 \mathrm{~d}$ & NA & BNR & BNR & BNR & BNR \\
\hline C9 & $7 \mathrm{~m}$ & NA & OP & $\mathrm{OP}$ & OP & OP \\
\hline C10 & $4 \mathrm{~m} 28 \mathrm{~d}$ & BNR & NA & NA & BNR & BNR \\
\hline C11 & $5 \mathrm{~m} 2 \mathrm{~d}$ & BNR & NA & NA & BNR & BNR \\
\hline C12 & $1 \mathrm{~m} 15 \mathrm{~d}$ & BNR & NA & NA & BNR & BNR \\
\hline C13 & $2 \mathrm{~m} 4 \mathrm{~d}$ & BNR & NA & NA & BNR & BNR \\
\hline C14 & $1 \mathrm{~m}$ & BNR & NA & NA & BNR & BNR \\
\hline C15 & $5 \mathrm{~m} 20 \mathrm{~d}$ & NA & NO & NO & BNR & NO \\
\hline C16 & $2 \mathrm{~m} 13 \mathrm{~d}$ & BNR & NA & NA & NO & NO \\
\hline C17 & $8 \mathrm{~m} 8 \mathrm{~d}$ & NA & NO & NO & NO & NO \\
\hline C18 & $9 \mathrm{~m} 21 \mathrm{~d}$ & NA & BNR & $\mathrm{Q}$ & BNR & BNR \\
\hline C19 & $9 \mathrm{~m} 25 \mathrm{~d}$ & NA & BNR & BNR & BNR & BNR \\
\hline $\mathrm{C} 20$ & $11 \mathrm{~m} 7 \mathrm{~d}$ & NA & BNR & BNR & BNR & BNR \\
\hline
\end{tabular}

Note: NA—Not assessed in the age range; BNR—Between normal range; NO—Non optimal; OP—Optimal profile; Q—Questionable.

In the quality of moment factor $85 \%$ of babies demonstrated normal pattern of development. The other $15 \%$ was ranked as follows: one had a questionable profile, another had non optimal, and the third had a slightly delayed profile. That means some neuromotor functions as those that coordinates the fine and gross motor control, and quality of movement, are decreasing in these children. The assessment of the motor quality of babies in the behavior scale was a positive complementation for the motor assessment in general. Therefore, in this area, one must pay attention in early investigating babies with motor problems in order to create stimulating investigations in the sense to enable children to explore the environment, consequently, favor the psychomotor development in general (Janssen et al., 2008).

The most severe changes indicated by the scale, considering the indexes of mental development and behavior scales, were found in three children sheltered for more than two months: C4, C5 and C17. Due to the reduced time in the shelter, it is supposed that the developmental problems were already present before the institutionalization and there were misconduct of the staff in not identifying such conditions in the admission individual charts. Hermenau, Hecker, Elbert and Ruf-Leuschner (2014) state that the institution sometimes cannot provide adequate support for a proper development of children who were victims of physical assault, additionally, in some cases they can support the appearance of alterations in mental health, such as aggressiveness and depression. According to that study performed in Tanzania, besides children there were also babies, which had a great impact in the emergence of development changes at older ages, for this age is considered to have care and attention as priority.

From Bayley II assessments in the current research, ten babies that were welcomed in the institution, only some days old (Table 3), presented performances appropriate for their age, that is, showed a normal pattern of child development, hence demonstrating that the environment, somehow, positively interfere for the healthy performance of these children. These data is in agreement with the study performed with children aging between 2 and 12 months in a mental health institution, whose development took place with no severe disturbances, chiefly regarding psychomotor aspects and the interaction with people and objects (Lecannelier, Silva, Hoff- 
mann, Melo, \& Morales, 2014).

The results demonstrated here by Bayley II scales show that even though there are some changes in the development of some babies, those changes may be modified, as most babies presented performances within normality, without specific indicators of deficiency or severe development delay. Nevertheless, it is thought that the stimulation and intervention in these situations in sheltering services must always be priority, even though the frequency is lower in comparison to other children with proved delay risk. The changes that happen in the first two years of life are very intense and fast, and on that account, more likely to aggravate. Moreover, that is the time the baby best respond to intervention and environment stimuli (Figueiras, Souza, Rios, \& Yehuda, 2005; Santos \& Campos, 2010).

\section{Conclusion}

The objective of this study was to assess the development of babies aging from 1 to 12 months, attended at a temporary sheltering institution for children in the North of Brazil, by the use of a child assessment scale, Bayley II. The research didn't intend to generalize the results to other children. Though, it is expected that the study contributes for the researches on the use of this assessment method as a complement to construct the individual assistance plan (IAP), considering other information sources as social, family, and medical history in the study and interventions planning for the healthy child development.

It is mandatory that public policies are proactive in the assistance of children that need institutional shelter. To manage the primary causes of abandonment, as: support and services provided for the families in social vulnerability, incentive to education, prevention and monitoring or early pregnancy, and the use of drugs by the person responsible, among other things, are important to prevent sending children to institutions. Although, the current situation must also be dealt with in order to provide adequate conditions for a proper development of children that are already in such places and those that continue entering every day.

This study presents some limitations as the reduced sample amount, and single assessments of each child. The limit scores originally developed for the American population were followed, context in which the Bayley II scale was developed. For future studies that will make use of development scales it is expected that some changes are made, in order to adequate it to the development marks of the Brazilian children.

At last, we emphasize that the results indicate the need for better investment in researches to early detect the possible delays in the child development in order to formulate effective monitoring and interventions.

\section{Funding}

Research funded by CNPq, registration number 420559/2013-2 and UFPA/PROPESP.

\section{References}

Barcons, N., Abrines, N., Brun, C., Sartini, C., Fumadó, V., \& Marre, D. (2012). Social Relationships in Children from Intercountry Adoption. Children and Youth Services Review, 34, 955-961. http://dx.doi.org/10.1016/j.childyouth.2012.01.028

Bayley, N. (1993). Bayley Scale of Infants Development. San Antonio: Psychological Corporation.

Brasil (2009). Lei $\mathrm{n}^{\circ}$ 12.010, de 3 de agosto de 2009. http://www.planalto.gov.br/ccivil_03/_Ato20072010/2009/Lei/L12010.htm

Cardona, J. F., Manes, F., Escobar, J., López, J., \& Ibáñez, A. (2012). Potential Consequences of Abandonment in Preschool-Age: Neuropsychological Findings in Institutionalized Children. Behavioural Neurology, 25, 291-301. http://dx.doi.org/10.1155/2012/782624

Conti, G., Hansman, C., Heckman, J. J., Novak, M. F., Ruggiero, A., \& Suomi, S. J. (2012). Primate Evidence on the Late Health Effects of Early-Life Adversity. Proceedings of the National Academy of Sciences, 109, 8866-8871. http://dx.doi.org/10.1073/pnas.1205340109

Conselho Nacional do Ministério Público (2013). Relatório da Infância e Juventude-Resolução no 71/2011: Um olhar mais atento aos serviços de acolhimento de crianças e adolescentes no País. Brasília: Conselho Nacional do Ministério Público, 108 p. http://www.cnmp.mp.br/portal/images/stories/Destaques/Publicacoes/Res_71_VOLUME_1_WEB_.PDF

Corrêa, L. da S., \& Cavalcante, L. I. C. (2013). Educadores de abrigo: Concepções sobre desenvolvimento e práticas de cuidado em situação de brincadeira. Revista Brasileira Crescimento Desenvolvimento Humano, 23, 309-317.

Cruz, E. J. da S., Dias, G. B., \& Pedroso, J. da S. (2014). Estudo com “Ages and Stages Questionnaires” com cuidadores de 
crianças institucionalizadas. Psico-USF, 19, 411-420. http://dx.doi.org/10.1590/1413-82712014019003004

Desmarais, C., Roeber, B. J., Smith, M. E., \& Pollak, S. D. (2012). Sentence Comprehension in Postinstitutionalized SchoolAge Children. Journal of Speech, Language and Hearing Research, 55, 45-54. http://dx.doi.org/10.1044/1092-4388(2011/10-0246)

Figueiras, A. C., Souza, I. C. N., Rios, V. G., \& Yehuda, B. G. V. (2005). Vigilância do desenvolvimento infantil no contexto da Atenção Integrada as doenças Prevalentes da Infância (AIDPI) [Manual]. Organização Pan Americana de Saúde. http://www.amro.who.int/spanish/ad/fch/ca/si-desenvolvimento.pdf

Golin, G., \& Benetti, S. P. da C. (2013). Acolhimento Precoce e o Vínculo na Institucionalização. Psicologia: Teoria e Pesquisa, 29, 241-248. http://dx.doi.org/10.1590/S0102-37722013000300001

Hermenau, K., Hecker, T., Elbert, T., \& Ruf-Leuschner, M. (2014). Maltreatment and Mental Health in Institutional Care Comparing Early and Late Institutionalized Children in Tanzania. Infant Mental Health Journal, 35, 102-110. http://dx.doi.org/10.1002/imhj.21440

Janssen, A. J. W. M., Nijhuis-van der Sanden, M. W. G., Akkermans, R. P., Oostendorp, R. A. B., \& Kollée, L. A. A. (2008). Influence of Behaviour and Risk Factors on Motor Performance in Preterm Infants at Age 2 to 3 Years. Developmental Medicine \& Child Neurology, 50, 926-931. http://dx.doi.org/10.1111/j.1469-8749.2008.03108.x

Lecannelier, F., Silva, J. R., Hoffmann, M., Melo, R., \& Morales, R. (2014). Effects of an Intervention to Promote Socioemotional Development in Terms of Attachment Security a Study in Early Institutionalization in Chile. Infant Mental Health Journal, 35, 151-159. http://dx.doi.org/10.1002/imhj.21436

Manso, J. M. M., García-Baamonde, M. E., \& Alonso, M. B. (2011). Design of a Language Stimulation Program for Children Suffering Abuse. Children and Youth Services Review, 33, 1325-1331. http://dx.doi.org/10.1016/j.childyouth.2011.03.003

McLaughlin, K. A., Fox, N. A., Zeanah, C. H., \& Nelson, C. A. (2011). Adverse Rearing Environments and Neural Development in Children: The Development of Frontal Electroencephalogram Asymmetry. Biological Psychiatry, 70, 10081015. http://dx.doi.org/10.1016/j.biopsych.2011.08.006

Muhamedrahimov, R. J., Agarkova, V. V., Vershnina, E. A., Palmov, O. I., Nikiforova, N. V., Mccall, R. B., \& Groark, C. J. (2014). Behavior Problems in Children Transferred from a Socioemotionally Depriving Institution to St. Petersburg (Russia Federation) Families. Infant Mental Health Journal, 35, 111-122. http://dx.doi.org/10.1002/imhj.21435

Müller, F. (2014). Perspectivas de crianças acolhidas institucionalmente sobre suas famílias de origem. Linhas Críticas, 20, 125-145.

Nelson, C. A., Bos, K., Gunnar, M. R., \& Sonuga-Barke, E. J. (2011). V. The Neurobiological Toll of Early Human Deprivation. Monographs of the Society for Research in Child Development, 76, 127-146. http://dx.doi.org/10.1111/j.1540-5834.2011.00630.x

Oliveira, C. A. de O., \& Pereira, E. G. (2011). Estudo sobre a Lei Nacional de Adoção: Institucionalização, acolhimento familiar e cadastros. Contextos Clínicos, 4, 113-122. http://dx.doi.org/10.4013/ctc.2011.42.05

Pajulo, M., Pyykkönen, N., Kalland, M., Sinkkonen, J., Helenius, H., Punamäki, R. L., \& Suchman, N. (2012). SubstanceAbusing Mothers in Residential Treatment with Their Babies: Importance of Pre- and Postnatal Maternal Reflective Functioning. Infant Mental Health Journal, 33, 70-81. http://dx.doi.org/10.1002/imhj.20342

Reis, A. B. R., Mello, R. R. D., Morsch, D. S., Meio, M. D. B. B., \& Silva, K. S. D. (2012). Desempenho mental de bebês pré-termo de muito baixo peso ao nascer: Avaliação da estabilidade nos dois primeiros anos de vida e fatores associados ao desempenho mental. Revista Brasileira de Epidemiologia, 15, 13-24.

http://dx.doi.org/10.1590/S1415-790X2012000100002

Santos, C. C. D., \& Campos, D. (2010). Desenvolvimento motor: Fundamentos para Diagnóstico e intervenção. In M. V. L. Moura-Ribeiro, \& V. M. G. Gonçalves (Orgs.), Neurologia do Desenvolvimento da Criança (pp. 288-307). Rio de Janeiro: Revinter.

Schlesiger, C., Lorenz, J., Weinert, S., Schneider, T., \& Roßbach, H. G. (2011). 12 from Birth to Early Child Care. Zeitschrift für Erziehungswissenschaft, 14, 187-202. http://dx.doi.org/10.1007/s11618-011-0186-3

Siqueira, A. C., \& Dell’Aglio, D. D. (2006). O impacto da institucionalização na infância e na adolescência: Uma revisão de literatura. Psicologia \& Sociedade, 18, 71-80. http://dx.doi.org/10.1590/S0102-71822006000100010

Smyke, A. T., Zeanah, C. H., Gleason, M. M., Drury, S. S., Fox, N. A., Nelson, C. A., \& Guthrie, D. (2012). A Randomized Controlled Trial Comparing Foster Care and Institutional Care for Children with Signs of Reactive Attachment Disorder. American Journal of Psychiatry, 169, 508-514. http://dx.doi.org/10.1176/appi.ajp.2011.11050748

Soysal, A. S., Gucuyener, K., Ergenekon, E., Turan, Ö., Koc, E., Turkyılmaz, C., \& Atalay, Y. (2014). The Prediction of Later Neurodevelopmental Status of Preterm Infants at Ages 7 to 10 Years Using the Bayley Infant Neurodevelopmental Screener. Journal of Child Neurology, 29, 1349-1355. http://dx.doi.org/10.1177/0883073813520495

Spitz, R. A. (2004). O primeiro ano de vida: Um estudo psicanalítico do desenvolvimento normal e anômalo das relações 
objetais. São Paulo: Martins Fontes.

Tizard, J., \& Tizard, B. (1967). The Social Development of Two-Year-Old Children in Residential Nurseries. In H. R. Schaffer (Ed.), The Origins of Human Social Relation (pp. 147-160). London: Academic Press.

Tizard, B., \& Joseph, A. (1970). Cognitive Development of Young Children in Residential Care: A Study of Children Aged 24 Months. Journal of Child Psychology and Psychiatry, 11, 177-186. http://dx.doi.org/10.1111/j.1469-7610.1970.tb01024.x

Tizard, B., \& Rees, J. (1974). A Comparison of the Effects of Adoption, Restoration to the Natural Mother, and Continued Institutionalization on the Cognitive Development of Four-Year-Old Children. Child Development, 45, 92-99. http://dx.doi.org/10.2307/1127754

Van IJzendoorn, M. H., Palacios, J., Sonuga-Barke, E. J. S., Gunnar, M. R., Vorria, P., McCall, R. B., Juffer, F. et al. (2011). I. Children in Institutional Care: Delayed Development and Resilience. Monographs of the Society for Research in Child Development, 76, 8-30. http://dx.doi.org/10.1111/j.1540-5834.2011.00626.x 